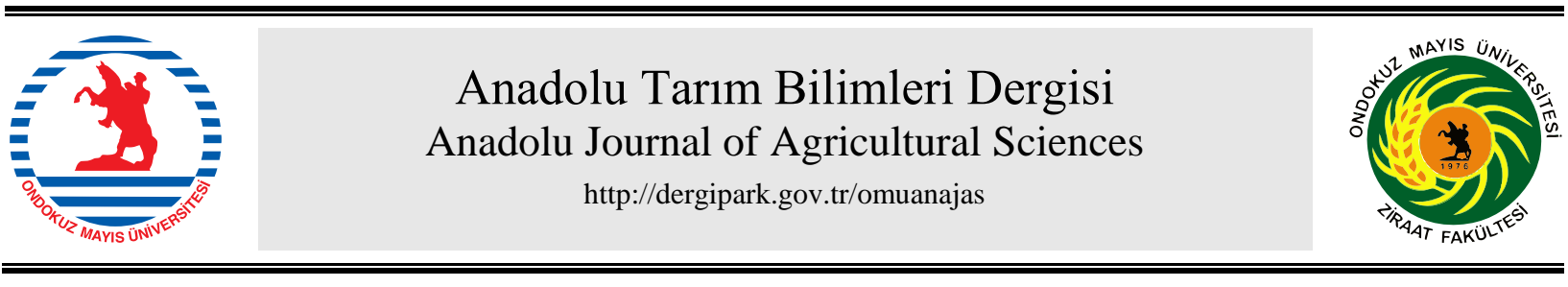

Araştırma/Research

Anadolu Tarım Bilim. Derg./Anadolu J Agr Sci, 32 (2017)

ISSN: 1308-8750 (Print) 1308-8769 (Online)

doi: 10.7161/omuanajas.296511

\title{
Otlatma olgunluğundaki doğal meranın familyalar bazında besleme değeri
}

\author{
Duygu Algan ${ }^{\mathrm{a}}$ İbrahim Aydın ${ }^{\mathrm{a}}$, Mustafa Olfaz ${ }^{\mathrm{b}}$ \\ ${ }^{a}$ Ondokuz Mayls Üniversitesi, Ziraat Fakültesi, Tarla Bitkileri Bölümü, 55139, Kurupelit, Samsun, Türkiye \\ ${ }^{b}$ Ondokuz Mayls Üniversitesi, Ziraat Fakültesi, Zootekni Bölümü, 55139, Kurupelit, Samsun, Türkiye \\ *Sorumlu yazar/corresponding author: iaydin@ omu.edu.tr
}

Geliş/Received 06/03/2017Kabul/Accepted 18/09/2017

\begin{abstract}
ÖZET
Meraların verimliliği ve üretilen otun kalitesi bitki türlerinin özelliği ve botanik kompozisyon tarafından belirlenir. Bu çalışmanın amacı doğal merada bulunan bitki türlerinin familya bazında besin maddeleri içeriklerini otlayan hayvanların ihtiyaçları açısından incelemektir. Araştırma sonucunda, ham protein (HP) içeriği bakımından, baklagiller familyasına dahil türlerin oldukça zengin, diğer familyaların yeterli ve buğdaygillerin ise yetersiz olduğu belirlenmiştir. Kalite faktörü açısından incelendiğinde; asit çözücülerde çözünmeyen lifli bileşikler bakımından, meradaki baklagiller ve diğer familyaların 1. sınıf, buğdaygiller familyasına dahil türlerin ise 2. sınıfta yer aldığı görülmektedir. Nötral çözücülerde çözünmeyen lifli bileşikler açısından ise meradaki baklagiller ve diğer familyalar 1 . sınıfta", buğdaygil familyasına ait bitkiler ise 4 . sınıfta" yer almaktadır. Baklagil, buğdaygil ve diğer familyaların nispi yem değerleri sırasıyla 145.6, 90.4 ve 125.9 olarak tespit edilmiştir. Meralarda otlayan hayvanların metabolik enerji (ME) ihtiyaçlarının karşılanması açısından, baklagiller ve diğer familyaların yeterli, buğdaygiller familyasına dahil türlerin ise yetersiz olduğu belirlenmiştir. Meralarda bulunan bitki familyaları arasında hayvanların besin maddeleri ihtiyaçlarını karşılama yetenekleri bakımından belirgin farklılıklar vardır. Hayvanların HP, sindirilebilir kuru madde ve ME ihtiyaçlarının karşılanabilmesi açısından meralarda yeterli oranda baklagil ve diğer familyaların bulunması hayati bir önem taşımaktadır.
\end{abstract}

Nutritive value of rangeland in the grazing maturity on the family basis

\section{ABSTRACT}

Yield and the quality of the rangeland depend on the botanical composition. The purpose of this study is to investigate the nutrient content of the plants available in a native rangeland on the family basis with respect to the nutritional requirements of the livestock grazing on that rangeland. The results of the study showed that the legumes found on the rangeland were rich in crude protein (CP) content while other species belonging the other families were sufficient with the exception of grasses, which was insufficient. With respect to the quality factor, it was found that legumes and other families were "first class" in terms of their acid detergent fiber content with the exception of grasses, which was classified as "second class". Moreover, it was found that legumes and other families were "first class" in terms of their neutral detergent fiber content with the exception of grasses, which was classified as "4th grade". The relative feed value of the species belonging to legumes, grasses and other families were found as 145.6, 90.4 and 125.9, respectively. Legumes and species belonging to other families were found sufficient while grass species were found insufficient in terms of their ability to meet the metabolic energy (ME) requirements of the livestock grazing on the rangeland. There are marked differences between plant families found in rangelands in terms of their abilities to meet nutrient requirements of animals. As a result, the presence of legumes and the other families in adequate amounts is vital for meeting the $\mathrm{CP}$, digestible dry matter and $\mathrm{ME}$ requirements of animals. Anahtar Sözcükler: Botanik kompozisyon Ham protein Kalite Metabolik enerji Nispi yem değeri Bu çalıssma Duygu Algan'ın doktora tezinin bir kısmından yararlanılarak hazırlanmıştır.

\section{Giriş}

Meralar ülkemizin ve dünyanın en önemli kaba yem kaynaklarıdır. Mera vejetasyonları fonksiyonel grup olarak farklı familyalara ait bitkilerden oluşan kompoze bir topluluktur. Otun niteliğinden kaynaklanmak üzere, hayvansal ürüne dönüşüm oranı açısından familyalar ve türler arasında belirgin bir farklılık vardır. Bazı 
araştırmacılar, kaliteli kaba yem kullanımı ile hayvansal üretimde $\%$ 40-50 daha fazla verim artış1 sağlanabileceğini belirtmektedir (Ball ve ark., 2001; Kemp ve ark., 2010). Kaba yemin kalitesi açısından en önemli parametre HP içeriğidir (Gillen ve Berg, 1998). Kaba yemlerin sindirilebilirliği ve dolayısıyla yem değeri HP içeriğine bağlı olarak artar (Van Soest, 1973). Hayvanlara sağlanan $1.8 \mathrm{~kg}$ HP'nin $1 \mathrm{~kg}$ kemikli ete dönüştügü bildirilmektedir (NRC, 2007). HP dışında, yemlerin kalite göstergesi olarak genellikle sindirilebilir kuru madde (SKM), toplam sindirilebilir besin maddesi (TSM) ve ME gibi parametreler de kullanılmaktadır (White ve Wight, 1984; Pinkerton ve ark., 1991; France ve ark., 2000).

Son yıllarda kaba yemlerin teorik besin değerinin belirlenmesinde ve borsalarda satılmasında nispi yem değerinin (NYD) kullanımı yaygınlaşmaktadır. Bir yemin NYD'si, o yemin asit çözücülerde çözünmeyen lifli bileşikler (ADF) ve nötral çözücülerde çözünmeyen lifli bileşiklerin (NDF) içeriği ile ilgilidir. Nitekim hayvanların istekli yem tüketimi, yemlerin ADF içeriği ile ilişkili iken, yemlerin sindirilebilirliği NDF içeriği ile ilgilidir. Yemlerdeki yüksek NDF içeriğgi sindirimi yavaşlattı̆̆ından dolayı, fiziksel olarak hayvanların tokluk hissetmesine neden olur ve tüketim düșer (Van Soest, 1994). Belyea ve ark. (1993), çiftlik hayvanlarının ME ihtiyaçlarının belirlenmesinde yemlerdeki NDF ve ADF miktarının belirleyici iki faktör olduğunu ifade etmişlerdir.

Yemlerin NYD'sinin hesaplanmasında protein oranı dikkate alınmamaktadır. NYD yoncada tam çiçeklenme döneminde 100 olarak kabul edilir ve diğer türler bu orana göre değerlendirilir. Besin içeriği açısından baklagil ve buğdaygil familyaları arasında net bir farklılık bulunmaktadır. Buğdaygil yem bitkilerinin ADF ve NDF içerikleri, baklagillere göre genelde daha yüksektir. Dolayısıyla buğdaygiller, baklagillere göre daha düşük NYD'ye sahiptirler. Diğer taraftan mera alanlarında baklagiller familyasına dahil bitki türleri, buğdaygillere göre yaklaşık 2 kat daha fazla HP içermektedir (Aydin ve Uzun, 2005). Hayvanların sindirim sistemleri açısından kaba yemlerde belirli düzeye kadar selülozun bulunması gerekir. Ancak bir noktadan sonra yemlerde ADF ve NDF oranının artması, kaba yemlerin besleme değerini önemli ölçüde azaltır. Yem bitkileri türlerinde NDF içeriği açısından farklılık, ADF içeriğine göre çok daha yüksek olabilir (Pak, 2016). Yem bitkilerinde türler ve genotipler NYD bakımından birbirinden oldukça farklı olabilirler (Yavuz, 2005; Canpolat ve Karaman, 2009; Albayrak ve ark., 2011; Çınar, 2012).

Yemin kalitesi, hayvanların besin madde ihtiyaçlarının karşılanmasında o yemin kapasitesi olarak tanımlanır (Adesogan ve ark., 2006; Newman ve ark., 2006). Hayvanların yemlenme davranışı, yem tüketimi, yemin sindirilebilirliği ve hayvansal ürüne dönüşüm oranı yemin kalitesine bağlı olarak değişir (Van Soest, 1994; Pavlu ve ark., 2006; Schut ve ark., 2010). Çok sayıda türden meydana gelen meraların, otlatma kapasitelerinin belirlenmesinde meradaki otun miktarı kadar, otun kalitesi de önem taşımaktadır (Tallowin ve Jefferson, 1999; Bruinenberg ve ark., 2002; Jouven ve ark., 2006). Meralarda ot kalitesi büyük oranda botanik kompozisyon tarafindan belirlenir (Samuel ve Hard, 1998; Koc, 2013). Yemin kalitesini etkileyen diğer faktörler; bitkinin büyüme devresi, iklim, toprak, sicaklık ve amenajman ilkelerine uyumluluktur (Erkovan ve ark., 2009; Schut ve ark., 2010; Koc ve ark., 2014).

Yem değeri yüksek olan bitkilerin hayvansal ürüne dönüşüm oranı da yüksektir. Bu açıdan baklagil türleri buğdaygillere göre daha üstündür. Kemp ve ark. (2010), ak üçgül ve çayır üçgülünün bulunduğu meralarda otlayan hayvanların, çok yıllık çimin dominant olduğu meralarda beslenenlere göre \% 40 daha fazla canlı ağırlık artışı sağladığını belirtmektedirler. Baklagillerce zengin meraların buğdaygillerin dominant olduğu meralara göre hayvanlarda daha yüksek performans oluşturacağ b; Keady ve Hanrahan, 2010). Ball ve ark. (2001), yonca ile beslenen sığırların, domuz ayrığı + ak üçgül karışımından oluşan merada beslenenlere göre \% 50 daha fazla canlı ağılık kazancına sahip olduğunu vurgulamaktadırlar. Corriher ve ark. (2009), baklagil yem bitkisi türlerinin yer aldığı yapay merada otlayan sığırların, buğdaygil bitkilerinden oluşan meradaki hayvanlara göre daha fazla canlı ağırlık artışına sahip olduğunu bildirmektedirler. Schreurs ve ark. (2007a, b) ise, ak üçgül bakımından zengin meralarda otlayan hayvanların etlerinin, buğdaygillerce zengin merada otlayan hayvanların etlerine göre daha fazla tercih edildiğini belirtmektedirler. Sadece baklagil ve buğdaygil bitkileri değil, diğer familyalara ait bitkiler de meranın kalitesi açısından önem taşırlar. Hindiba ve sinir otları türleri, çok yıllık çim bitkisine göre hayvanlar açısından çok daha fazla besleyicidirler (Barry, 1998; Moorhead ve ark., 2002; Li ve Kemp, 2005).

Meraların niteliği büyük ölçüde iklim, toprak ve botanik kompozisyon tarafindan belirlenir. Bu nedenle sürdürülebilir bir verimlilik açısından meralarda farklı familyalara sahip türlerin belirli bir oranda bulunması mera yönetimi açısından hayati bir önem taşımaktadır. $\mathrm{Bu}$ araştırma, doğal bir merada bulunan familyaların besleme değerlerini belirlemek amacıyla yürütülmüsşür.

\section{Materyal ve Yöntem}

Otlatma olgunluğundaki doğal meranın familyalarına ait veriler, üstten tohumlama (tohumlama yapılan ve yapılmayan) ve farklı gübre dozlarının (azotun ve fosforun 3'er (0, 6 ve $\left.12 \mathrm{~kg} \mathrm{da}^{-1}\right)$ ve potasyumun 2 ( 0 ve $\left.8 \mathrm{~kg} \mathrm{da}^{-1}\right)$ dozu), meranın verim ve ot kalitesine etkilerini belirlemek amaciyla kurulan denemeden elde edilmiştir (Aydın ve ark., 2016). Denemede gübre olarak amonyum nitrat $\left(\begin{array}{lll}\% & 33 & \mathrm{~N}\end{array}\right)$, potasyum sülfat $\left(\% 50 \mathrm{~K}_{2} \mathrm{O}\right)$ ve triple süper fosfat $(\% 46$ $\mathrm{P}_{2} \mathrm{O}_{5}$ ) kullanılmıştır. Söz konusu deneme, Samsun ili, 
Ondokuz Mayıs ilçesinde toprağın karakterleri bakımından tınlı, pH bakımından nötr (7.1), az kireçli (2.5) ve tuzsuz (0.016) olan ve aynı zamanda, fosfor içeriği çok az $\left(2.54 \mathrm{~kg} \mathrm{da}^{-1}\right)$, potasyum içeriği fazla (43 $\left.\mathrm{kg} \mathrm{da}^{-1}\right)$ ve organik madde içeriği orta seviyede $(\% 2.07)$ olan doğal bir merada yürütülmüştür. Deneme süresince toplam yağış ve ortalama sıcaklık bakımından iklimsel özellikleri $578.3 \mathrm{~mm}$ ve $776.2 \mathrm{~mm}$ ile $16.0{ }^{\circ} \mathrm{C}$ ve 15.5 ${ }^{\circ} \mathrm{C}$ arasında değişmiştir (MGM, 2015). Meradaki bitkilerin familyalar bazında besin değerlerinin belirlenmesinde, üstten tohumlama ve farklı gübre uygulamalarının etkilerinden bağımsız olarak, bu işlemlerin ortalama verileri dikkate alınmıştır.

İlgili araştırmadan elde edilen familyalara ait hasat özellikleri ve dominant bitki türleri aşağıdaki şekilde bildirilmiştir. Hasat, her biri $12 \mathrm{~m}^{2}$ olan parsellerin $6 \mathrm{~m}^{2}$ alanından dominant bitkilerin tam çiçeklenme döneminde yapılmış ve bitki türleri baklagil, buğdaygil ve diğer familyalar olarak ayrılmıştır. Baklagillere ait dominant bitki türlerini ak üçgül (Trifolium repens L.) ve yonca (Medicago sativa L.) oluştururken, bunları şerbetçiotu yoncası (Medicago lupilina L.), arap yoncası (Medicaga arabica (L.) Huds.), mini yonca (Medicago minima (L.) Bart.), anadolu üçgülü (Trifolium resupinatum L.) ve gelemen üçgülü (Trifolium meneghinianum (L.) Clem.) takip etmiştir. Buğdaygiller familyasında ise domuz ayrığı (Dactylis glomerata L.), çok yıllık çim (Lolium perenne L.) ve mavi ayrık (Agropyron intermedium (Host.) Beauv.) dominant türler olurken, kaba brom (Bromus racemosus L.), çayır salkım otu (Poa pratensis L), ve çayır tilkikuyruğu (Alopecurus pratensis L.) bitkileri araştırma sahasında rastlanan türler olarak kaydedilmiştir. Diğer familyalara dahil türler ise sinir otu (Plantoga lanceolata L.), çayırgüzeli (Bellis perennis L.), turna gagası (Geranium asphodeloides Burm. fil.), kızıl turna gagası (Erodium cicutarium (L.) Her.), kuzu kulağ 1 (Rumex acetosella L.), aslan dişi (Taraxacum scaturiginosum G. Hagl.), akyıldız (Ornithogalum orthophllum Ten.) ve Parentucellia latifolia (L.) Caruel türlerinden oluşmuştur.

Her bir familyaya ilişkin HP (Uzun, 2010), ADF ve NDF içerikleri (ANKOM, 2003) belirlenen değerler SKM (Eşitlik 1), kuru madde tüketimi (KMT, Eşitlik 2), NYD (Eşitlik 3) ve ME (Eşitlik 4) hesaplamalarında kullanılmıştır.

$\operatorname{SKM}(\%)=88.9-[0.779 \times A D F(\%)]$ (Undersander, 2003)

KMT (canlı ăgırlı̆̆ın \%'si olarak) (\%) = 120/[NDF (\%)] (Undersander, 2003)

$N Y D=[S K M(\%) \times K M T(\%)] / 1.29$ (Moore ve Undersander, 2003

$M E\left(M J g^{-1}\right)=0.17 \times[S K M(\%)]-2.0 \quad($ Belyea $\quad$ ve ark.,1993)

Baklagil, buğdayil ve baklagil karışımlarına ait kalite standartları Lacefield (1988)'e göre yapılmıştır (Çizelge 1). Familyaların KMT, HP ve ME değerlerinin yeterliliğini belirlemek için, $500 \mathrm{~kg}$ canlı ağırlığa sahip et ırkı bir sığırın KMT, HP ve ME ihtiyaçları (NRC, 1996) kıstas alınmıştır. Her bir familyaya ait KMT esas alınarak, bu KMT üzerinden sağlanan HP ve ME değerleri hesaplanmış ve hayvanın ihtiyacı ile karşılaştırılmıştır (Çizelge 2).

Çizelge 1. Baklagil, buğdayil ve baklagil karışımlarına ait kalite standartları

\begin{tabular}{|c|c|c|c|c|c|c|}
\hline $\begin{array}{l}\text { *Kalite } \\
\text { standartlar1 }\end{array}$ & $\mathrm{HP}^{\mathrm{a}}$ & $\mathrm{ADF}^{\mathrm{b}}$ & $\mathrm{NDF}^{\mathrm{c}}$ & $\mathrm{SKM}^{\mathrm{d}}$ & $\mathrm{KMT}^{\mathrm{e}}$ & $N Y D^{f}$ \\
\hline & \multicolumn{3}{|c|}{ **KM'nin \%'si } & $\%$ & **CA'ın \%'si & \\
\hline En iyi kalite & $>19$ & $<<31$ & $<<40$ & $>65$ & $>3.0$ & $>151$ \\
\hline 1 & $17-19$ & $31-35$ & $40-46$ & $62-65$ & $3.0-2.6$ & $151-125$ \\
\hline 2 & $14-16$ & $36-40$ & $47-53$ & $58-61$ & $2.5-2.3$ & $124-103$ \\
\hline 3 & $11-13$ & $41-42$ & $54-60$ & $56-57$ & $2.2-2.0$ & $102-87$ \\
\hline 4 & $8-10$ & $43-45$ & $61-65$ & $53-55$ & $1.9-1.8$ & $86-75$ \\
\hline 5 & $<<8$ & $>45$ & $>65$ & $<<53$ & $<<1.8$ & $<<75$ \\
\hline
\end{tabular}

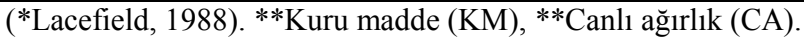

${ }^{a}$ Ham protein (HP), ${ }^{b}$ asit çözücülerde çözünmeyen lifli bileşikler (ADF), ${ }^{c}$ nötral çözücülerde çözünmeyen lifli bileşikler (NDF),

${ }^{d}$ sindirilebilir kuru madde (SKM), ${ }^{e}$ kuru madde tüketimi (KMT) ve ${ }^{f}$ nispi yem değeri (NYD)

\section{Bulgular ve Tartışma}

\subsection{Ham protein içeriği}

Ortalama HP içeriği baklagiller familyasında $191.1 \mathrm{~g} \mathrm{~kg}^{-1}$ ile en yüksek, bunu $151.0 \mathrm{~g} \mathrm{~kg}^{-1} \mathrm{HP}$ ortalaması ile diğer familyalar ve $130.2 \mathrm{~g} \mathrm{~kg}^{-1} \mathrm{HP}$ ortalaması ile buğdaygillere ait bitkiler izlemektedir (Şekil 1.a).

Familyaların HP içerikleri kalite standartları bakımından (Lacefield, 1988) sinıflandırıldığında, baklagillerin "en iyi kalitede", diğer familyaların "2. sınıf" ve buğdaygillerin ise " 3. sınıf" kalitede olduğu tespit edilmiştir (Çizelge 1). Bir sığırın $(500 \mathrm{~kg})$ günlük $1.4 \mathrm{~kg} \mathrm{HP}$ tüketmesi önerilmektedir (NRC, 1996). Baklagil, buğdaygil ve diğer familyaların KMT üzerinden hayvanlara sağlayabileceği HP miktarlarının ise sirasıyla $2.8,1.2$ ve $2.0 \mathrm{~kg}_{\text {gün }}{ }^{-1}$ olabileceği hesaplanmıştır (Çizelge 2). 

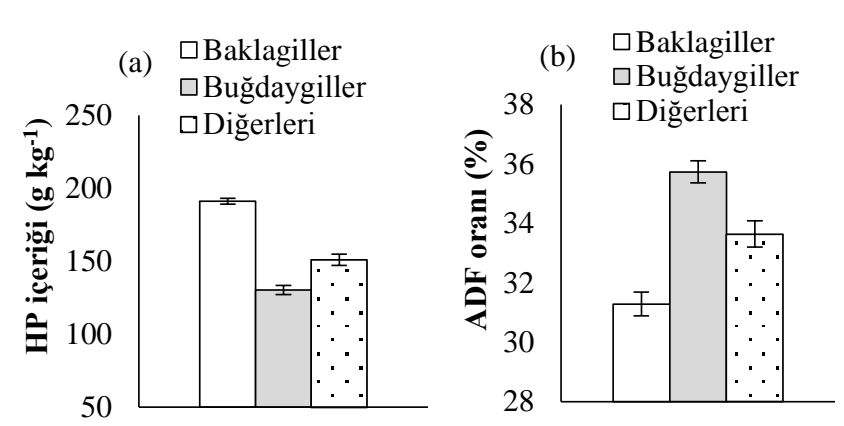
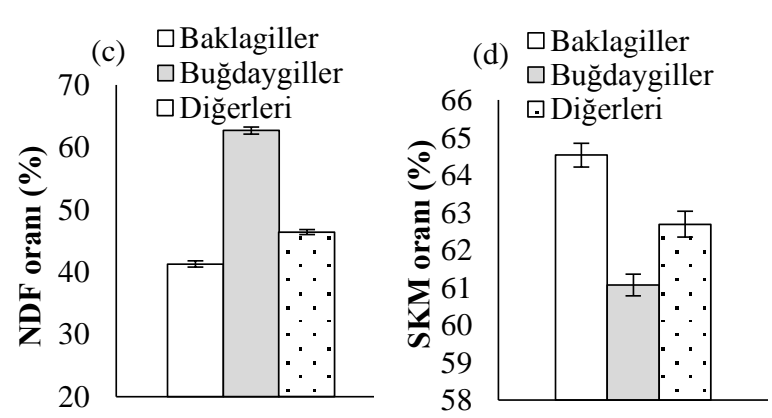

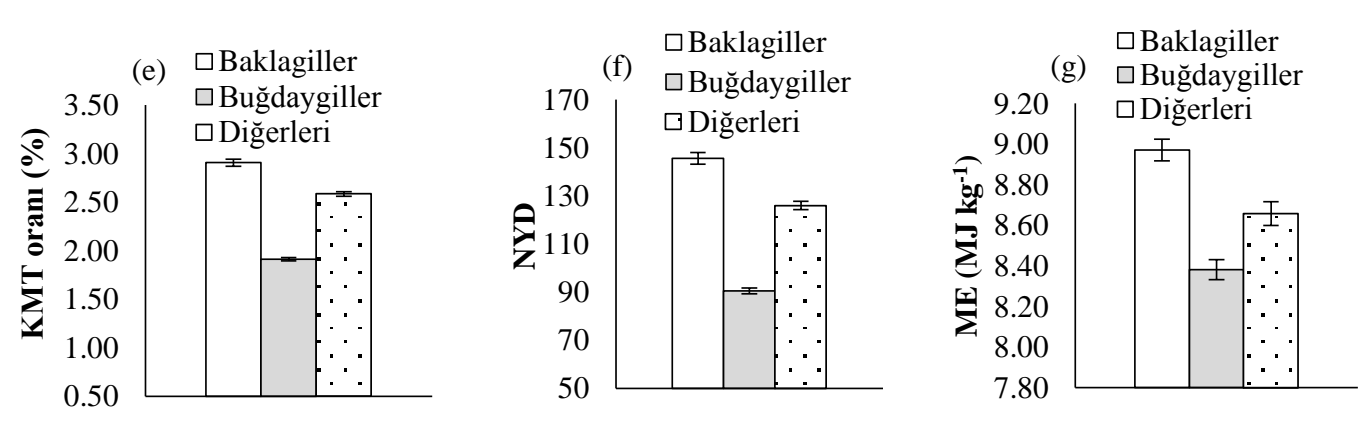

Şekil 1. Familyaların (a) HP (ham protein) içeriği $\left(\mathrm{g} \mathrm{kg}^{-1}\right)$, (b) ADF (asit çözücülerde çözünmeyen lifli bileşikler) oranı (\%), (c) NDF (nötral çözücülerde çözünmeyen lifli bileşikler) oranı (\%), (d) SKM (sindirilebilir kuru madde) oranı $(\%),(e)$ KMT (kuru madde tüketimi) oranı (\%), $(f)$ NYD (nispi yem değeri) ve $(g)$ ME (metabolik enerji) $\left(\mathrm{MJ} \mathrm{kg}^{-1}\right)$ değerleri. * Hata çubukları standart hatayı göstermektedir

Çizelge 2. Familyaların besin içeriklerinin $500 \mathrm{~kg}$ canlı ağırlıktaki et ırkı bir sığırın günlük ihtiyaçlarıyla karşılaştırılması

\begin{tabular}{|c|c|c|c|c|}
\hline Özellik & İhtiyaç* & Baklagiller** & Buğdaygiller** & Diğger familyalar** \\
\hline${ }^{a} \mathrm{KMT}\left(\mathrm{kg}\right.$ gün $\left.{ }^{-1}\right)$ & 11.3 & $14.6+$ & $9.6-$ & $13.0+$ \\
\hline${ }^{b} \mathrm{HP}\left(\mathrm{kg}\right.$ gün $\left.{ }^{-1}\right)$ & 1.4 & $2.8+$ & $1.2-$ & $2.0+$ \\
\hline${ }^{c} \mathrm{ME}\left(\right.$ Mcal gün $\left.{ }^{-1}\right)$ & 24.2 & $31.2+$ & $19.2-$ & $26.9+$ \\
\hline
\end{tabular}

$\mathrm{Bu}$ duruma göre baklagil ve diğer familyaların hayvanların ihtiyaçlarından daha yüksek bir protein içeriğine sahip olduğu, buna karşın buğdaygillerin ise hayvan besleme açısından yetersiz HP ürettiği söylenebilir. Baklagil ve buğdaygil karışımına sahip bir meranın ise, HP açısından dengeli olabileceği görülmektedir.

\subsection{Asit çözücülerde çözünmeyen lifli bileşikler oranı}

Araştırmadan elde edilen sonuçlara göre, baklagiller familyası \% 31.3 ile en düşük ADF oranına sahipken, buğdaygiller familyası \% 35.7 ile en yüksek ADF ortalamasına sahiptir. Diğer familyaların ADF oranı ise ortalama \% 33.6 olarak bulunmuştur (Şekil 1.b). Familyalar arasında ADF oranı açısından belirgin bir farklılığın olmaması dikkat çekmektedir. Nitekim Pak (2016), mera bitkilerinde kalite açısından oluşan farklılıkta ADF oranının fazla bir katkısı olmadığını bildirmektedir. Kalite standartları açısından incelendiğinde, meradaki baklagil ve diğer familyaların "1. sınıf", buğdaygil familyasının ise " 2 . sınıf'ta" yer aldığı görülmektedir (Lacefield, 1988) (Çizelge 1).

\subsection{Nötral çözücülerde çözünmeyen lifli bileşikler oranı}

Araştırmadan elde edilen sonuçlara göre, familyalara ait NDF oranları arasında önemli farklılıklar gözlenmektedir. En yüksek NDF oranı buğdaygiller familyasına dahil bitkilerde (\% 62.7) bunu \% 46.4 ile diğer familyalar izlemektedir. En düşük NDF oranı ise \% 41.3 ile baklagiller familyasına dahil türlerde belirlenmiştir (Şekil 1.c). Baklagiller ve diğer familyalar "1. sınıf", buğdaygil familyasına dahil bitkilerin ise " 4 . sınıf'ta" yer aldığ 1 saptanmıştır (Lacefield, 1988) (Çizelge 1). Bilindiği üzere, NDF, ADF'den farklı 
olarak hemiselüloz içerir. Bu araştırmadan elde edilen sonuçlara göre, otlak alanlarında bulunan buğdaygil bitkileri baklagil ve diğer familyalara göre çok daha fazla hemiselüloz biriktirirler. Familyalar arasında NDF oranı açısından önemli farklılıklar bulunması, yem bitkilerinde NDF oranının kalite unsuru açısından en önemli değişken olduğunu göstermektedir. Yapılan diğer çalışmalarda da benzer sonuçlar elde edilmiştir (Erkovan ve ark., 2009; Dasci ve ark., 2010; Koc ve ark., 2014).

\subsection{Sindirilebilir kuru madde}

Baklagil, buğdaygil ve diğer familyaların ortalama SKM oranları sirasiyla \% 64.561 .1 ve 62.7 olarak bulunmuştur (Şekil 1.d). SKM oranları bakımından Lacefield (1988)'ın kalite standartlarına göre yapmış olduğu sınıflandırmada; baklagillerin ve diğer familyaların "1. sınıf", buğdaygillerin ise "2. sınıf"ta" yer aldığı belirlenmiştir (Çizelge 1).

Familyaların ADF oranları arasında büyük bir farklılık olmadığından, hesaplanan SKM oranları da birbirine yakın çıkmıştır.

\subsection{Kuru madde tüketimi}

Baklagil, buğdaygil ve diğer familyaların ortalama KMT oranları sirasiyla \% 2.91, 1.91 ve 2.59 olarak gerçekleşmiştir (Şekil 1.e). Buğdaygiller familyasına ait ortalama NDF oranı diğerlerine göre oldukça yüksek olduğundan, familyaların KMT oranları arasında çok belirgin farklılıklar tespit edilmiştir. KMT oranları açısından baklagil ve diğer familyaların, "1. sınıf" ve buğdaygillerin ise "4. sınıf" kalite standartlarında yer aldığı görülmektedir (Lacefield, 1988) (Çizelge 1).

\subsection{Nispi yem değeri}

Baklagil, buğdaygil ve diğer familyaların ortalama NYD'si sirasiyla $145.6, \quad 90.4$ ve 125.9 olarak belirlenmiştir (Şekil 1.f). Baklagil familyasına dahil türlerin ortalama NYD'si buğdaygillere göre \% 50'den daha fazladır. Kalite standartları açısından değerlendirildiğinde meradaki baklagillerin ve diğer familyaların " 1 . sınıf", buğdaygillerin ise " 3 . sinıf"ta" yer aldığı saptanmıştır (Lacefield, 1988) (Çizelge 1). Sürdürülebilir bir verimlilik ve yüksek hayvansal üretim açısından meralarda botanik kompozisyonun bileşenleri her zaman göz önünde bulundurulmalıdır. Nitekim baklagillerce zengin merada otlayan hayvanların, buğdaygillerin dominant olduğu meralarda beslenenlere göre çok daha fazla canlı ağırlık artışına sahip olduğu bildirilmektedir (Ball ve ark., 2001; Schreurs ve ark., 2007 a, b; Corriher ve ark., 2009; Keady ve Hanrahan, 2010). Burada dikkat çekici diğer bir husus, diğer familyaların besin değeri açısından buğdaygillere göre daha yüksek bir değere sahip olmalarıdır. Hayvanların severek tükettiği türleri kapsaması durumunda, meralarda diğer familyaların bulunması bir zenginlik olarak sayılabilir.

\subsection{Metabolik enerji}

Familyalara ilişkin ME değerleri Şekil 1.g'de verilmiştir. ME değerleri açısından familyalar arasında önemli farklılıklar belirlenmiştir. Baklagiller, buğdaygiller ve diğer familyaların ortalama ME değerleri sırasıyla $8.97,8.38$ ve $8.66 \mathrm{MJ} \mathrm{kg}^{-1}$ olarak gerçekleşmiştir. Bir sığır $(500 \mathrm{~kg})$ günde $24.2 \mathrm{Mcal}$ ME'ye ihtiyaç duymaktadır (NRC, 1996). Araştırmamızda baklagil, buğdaygil ve diğer familyaların KMT üzerinden sağladıkları ortalama ME değerleri sırasıyla $31.2,19.2,26.9 \mathrm{Mcal}_{\text {gün }}{ }^{-1}$ olarak hesaplanmıştır. ME değerleri açısından, baklagillerin ve diğer familyaların yeterli, buğdaygiller familyasına ait bitkilerin ise ihtiyacı karşılayamadığı görülmektedir (Çizelge 2).

\section{Sonuç}

Mera bitkilerinde kalite denildiğinde, üretilen otun hayvanların besin madde ihtiyacını karşılama durumu anlaşılır. Bitki besin içeriği açısından meralarda familyalar arasında belirgin bir farklılık vardır. Bilindiği üzere, otun kalitesi ile hayvansal performans arasinda çok yakın ilişki bulunmaktadır. Baklagil familyasına dahil türlerin dominant olduğu suni veya doğal meralarda otlayan hayvanların canlı ağırlık artışı, buğdaygillerin yoğun olduğu alanlarda otlayanlara göre \% 40 daha fazla olabilir. Sonuç olarak, hayvanların HP, SKM ve ME ihtiyaçlarının karşılanabilmesi için, meralarda yeterli oranda baklagil ve diğer familyaların bulunması hayati bir önem taşımaktadır. Bu nedenle, sürdürülebilir mera kullanımı ve üretilen otun kalitesi açısından yeterli oranda baklagiller familyasına ait türlerin yer alması gerektiği dikkate alınmalıdır.

\section{Teşekkür}

$\mathrm{Bu}$ çalışma, TÜBITTAK-TOVAG grubu tarafindan desteklenmiştir (Proje no: 112 O 742).

\section{Kaynaklar}

Adesogan, A.T., Sollenberger, L.E., Moore, J.E., 2006. Florida Forage handbook. C.G. Chambliss, University of Florida, Cooperative Extension Services, Florida.

Albayrak, S., Türk, M., Yüksel, O., Yılmaz, M., 2011. Forage yield and the quality of perennial legume-grass mixtures under rainfed conditions. Not Bot Hort Agrobot Cluj, 39(1): 114-118.

Ankom, 2003. Method for determining neutral detergent fiber, acid detergent fiber, crude fiber. Ankom Technology, Macedon, NY.

Aydın, İ., Olfaz, M., Algan, D., 2016. Bazı ıslah işlemlerinin doğal merada verim, botanik kompozisyon ve yemin mineral dengesinden kaynaklanan potansiyel hastalık risklerine etkileri. TÜBİTA-TOVAG, 112 O 742, Proje Kesin Sonuç Raporu, Samsun. 
Aydin, I., Uzun, F., 2005. Nitrogen and phosphorus fertilization of rangelands affects yield forage quality and botanical composition. European Journal of Agronomy, 23(1): 8-14. doi:10.1016/j.eja.2004.08.001.

Ball, D.M., Collins, M., Lacefield, G.D., Martin, N.P., Mertens, D.A., Olson, K.E., Putnam, D.H., Undersander, D.J., Wolf, M.W., 2001. Understanding forage quality. American Farm Bureau Federation Publication, 1-01, Park Ridge, IL, p. 16.

Barry, T.N., 1998. The feeding value of chicory (Chichorium intybus) for ruminant livestock. The Journal of Agricultural Science, 131(3): 251-257.

Belyea, R.L., Steevens, B., Garner, G., Whittier, J.C., Sewell, H., 1993. Using NDF and ADF to balance diet. University of Missouri Extension, G3161.

Bruinenberg, M., Valk, H., Korevaar, H., Struik, P., 2002. Factors affecting digestibility of temperate forages from seminatural grasslands: a review. Grass and Forage Science, 57(3): 292-301. doi:10.1046/j.13652494.2002.00327.x.

Canpolat, Ö., Karaman, Ş., 2009. Bazı baklagil kaba yemlerinin in vitro gaz üretimi, organik madde sindirimi, nispi yem değeri ve metabolik enerji içeriklerinin karşılaştırılması. Tarım Bilimleri Dergisi, 15(2): 188-195.

Corriher, V.A., Hill, G.M., Pringle, T.D., Mullinix, B.G., 2009. Forage-finished beef supplemented with corn and corn oil. The Professional Animal Scientist, 25(5): 586595. doi:10.15232/S1080-7446(15)30761-0.

Çınar, S., 2012. Çukurova taban koşullarında bazı çok yıllık sicak mevsim buğdaygil yem bitkilerinin yonca (Medicago sativa L.) ile uygun karışımlarının belirlenmesi. Doktora Tezi. Çukurova Üniversitesi Fen Bilimleri Enstitüsü, 151s, Adana.

Dasci, M., Gullap, M.K., Erkovan, H.I., Koc, A., 2010. Effects of phosphorus fertilizer and phosphorus solubilizing bacteria applications on clover dominant meadow: II. Chemical composition. Turkish Journal of Field Crops, 15(1): 18-24.

Erkovan, H.I., Gullap, M.K., Dasci, M., Koc,, A. 2009. Changes in leaf area index, forage quality and aboveground biomass in grazed and ungrazed rangelands of eastern Anatolia region. Tarım Bilimleri Dergisi, 15(3): 217-223.

France, J., Theodorou, M., Lowman, R., Beever, D., 2000. Feed evaluation for animal production, feeding systems and feed evaluation models. CABI Publishing. pp. 12-20.

Gillen, R.L., Berg, W.A. 1998. Nitrogen fertilization of a native grass planting in Western Oklahoma. Journal of Range Management, 51(4): 436-441. doi:10.2307/4003330.

Jouven, M., Carr"re, P., Baumont, R., 2006. Model predicting dynamics of biomass, structure and digestibility of herbage in managed permanent pastures, 1. Model description. Grass and Forage Science, 61(2): 112-124. doi:10.1111/j.1365-2494.2006.00515.x.

Keady, T.W.J., Hanrahan, J.P., 2010. An evaluation of tyfon and chicory, as the sole forage orin combination with perennial ryegrass on the performance of finishing lambs. Proceedings of the British Society and Animal Science, p. 151.

Kemp, P.D., Kenyon, P.R., Morris, S.T., 2010. The use of legume and herb forage species to create high performance pastures for sheep and cattle grazing systems. Sociedade Brasileira de Zootecnia, 39: 169-174. doi:10.1590/S151635982010001300019.
Koc, A., 2013. Phosphorus doses and application season affect hay yield, hay quality and botanical composition of clover dominant meadow in highlands of Turkey. Turkish Journal of Field Crops, 18(2): 205-210.

Koc, A., Kaya, A., Gullap, M.K., Erkovan, H.I., Macit, M., Karaoglu, M., 2014. The effect of supplemental concentrate feed on live weight gain of yearling heifers over grazing season in subirrigated rangelands of East Anatolia. Turkish Journal of Veterinary and Animal Sciences, 38(4): 278-284. doi: 10.3906/vet-1309-56.

Lacefield, G.D., 1988. Alfalfa hay quality makes the difference university of kentucky department of agronomy, AGR-137, Lexington, KY. http://www.ca.uky.edu/agc/pubs/agr/agr137/agr 137.htm/ (Erişim tarihi: 5 Şubat 2017).

Li, G., Kemp, P.D., 2005. Forage chicory (Cichorium intybus L.): A review of its agronomy and animal production. Advances in Agronomy, 88: 187-222.

MGM, 2015. https://www.mgm.gov.tr/veridegerlendirme/ilve-ilceler-istatistik.aspx?m=SAMSUN (Erişim tarihi: 15 Şubat 2016).

Moore, J.E., Undersander, D.J., 2002. Relative forage quality: An alternative to relative feed value and quality index, Proceedings of the 13th Annual Florida Ruminant Nutrition Symposium, University of Florida, U.S.A, pp. 16-32.

Moorhead, A.J.E., Judson, H.G., Stewart, A.V., 2002. Liveweight gain of lambs grazing 'Ceres Tonic' plantain (Plantago lanceolata) or perennial ryegrass (Lolium perenne). Proceedings of the New Zealand Society of Animal Production, 62: 171-173.

National Research Council, 1996. The Evaluation of Forensic Dna Evidence. Washington, (DC); National Academy Press.

National Research Council, 2007. Nutrient Requirements of Small Ruminants: Sheep, Goats, Cervids, and New World Camelids, 6th. ed, National Academy Press Washington, DC, USA.

Newman, Y.C., Lambert, B., Muir, J.P., 2006. Defining forage quality. The Texas A\&M University System, U.S. Department of Agriculture, and the County Commissioners Courts of Texas Cooperating, pp. 1-13.

Pak, B., 2016. Mera bitkilerinin besin içerikleri açısından karşılaştırılması. Yüksek lisans tezi. Ondokuz Mayıs Üniversitesi Fen Bilimleri Enstitüsü, 107s, Samsun.

Pavlu, V., Hejcman, M., Pavlu, L., Gaisler, J., Nežerková, P., 2006. Effect of continuous grazing on forage quality, quantity and animal performance. Agriculture, Ecosystems and Environment, 113: 349-355. doi:10.1016/j.agee.2005.10.010.

Pinkerton, B., Cross, D.L., Service, C.U.C.E., 1991. Forage quality. Cooperative Extension Service, Clemson University.

Samuel, M.J., Hart., R.H., 1998. Nitrogen fertilization, botanical composition and biomass production on mixedgrass rangeland. Journal Range Management, 51(4): 408416.

Schreurs, N.M., Marotti, D.M., Tavendale, M.H., Lane, G.A., Barry, T.N., Lopez-Villalobos, N., Mcnabb, W.C., 2007a. Concentration of indoles and other rumen metabolites in sheep after a meal of fresh white clover, perennial ryegrass or Lotus corniculatus and the appearance of indoles in the blood. Journal Science Food and Agriculture, 87(6): 10421051. doi:10.1002/jsfa.2804.

Schreurs, N.M., Mcnabb, W.C., Tavendale, M.H., Lane, G.A., 
Barry, T.N., Cummings, T., Fraser, K., Lopez-Villalobos, N., Ramirez-Restrepo, C.A., 2007b. Skatole and indole concentration of fat from lambs that had grazed perennial ryegrass/white clover pasture or Lotus corniculatus. Animal Feed Science and Technology, 138(3-4): 254-271. doi:10.1016/j.anifeedsci.2006.11.020.

Schut, A., Gherardi, S., Wood, D., 2010. Empirical models to quantify the nutritive characteristics of annual pastures in south-west Western Australia. Crop and Pasture Science, 61(1): 32-43. doi:10.1071/CP08438.

Tallowin, J., Jefferson, R., 1999. Hay production from lowland semi-natural grasslands: a review of implications for ruminant livestock systems. Grass and Forage Science, 54(2): 99-115. doi:10.1046/j.1365-2494.1999.00171.x.

Uzun, F., 2010. Azot analizi. In: Uzun, F. (Ed). Tarla Bitkilerinde Laboratuvar Analizleri (Uygulama Ders Notu). Ders Notu No:1, 28-34, Samsun.
Undersander, D., 2003. The new Forage Quality Indexconcepts and use, World's Forage Superbowl Contest. http://www.dfrc.ars.usda.gov/WDExpoPdfs/new Relative FQ index.pdf (Erişim tarihi: 12 Şubat 2017).

Van Soest, P.J., 1973. Composition and nutritive value of forages, The Science of grassland Agriculture Iowa State University Press, Ames, IA.

Van Soest, P.J., 1994. Nutritional ecology of the ruminant. Cornell University, Ithaca, p. 476.

White, L.M., Wight, J.R., 1984. Forage yield and quality of dryland grasses and legumes. Journal Range Management, 37(3): 233-236.

Yavuz, M., 2005. Bazı ruminant yemlerinin nispi yem değeri ve in vitro sindirim değerlerinin belirlenmesi. GOÜ, Ziraat Fakültesi Dergisi, 22(1): 97-101. 